\title{
Karol Wilczyński
}

Uniwersytet Jana Kochanowskiego, Kielce

karol.stanislaw.wilczynski@gmail.com

ORCID: https://orcid.org/0000-0002-9636-5244

\section{Przesłanki utworzenia samorządu zawodowego instruktorów nauki jazdy i egzaminatorów prawa jazdy w świetle art. 17 ust. 1 Konstytucji Rzeczypospolitej Polskiej}

\author{
http://dx.doi.org/10.12775/SIT.2021.017
}

Regulacja samorządu zawodowego w prawie polskim znalazła swoje miejsce przede wszystkim w art. 17 ust. 1 Konstytucji Rzeczypospolitej Polskiej z dnia 2 kwietnia 1997 r. ${ }^{1}$, który stanowi: „W drodze ustawy można tworzyć samorządy zawodowe, reprezentujące osoby wykonujące zawody zaufania publicznego i sprawujące pieczę nad należytym wykonywaniem tych zawodów w granicach interesu publicznego i dla jego ochrony"2. Wykładnia powołanego przepisu

${ }^{1}$ Dz.U. Nr 78, poz. 483 z zm.

2 Podkreślenia wymaga, że prawne podstawy działania samorządów zawodowych zostały zamieszczone w rozdziale pierwszym ustawy zasadniczej, zatytułowanym „Rzeczpospolita”, który zawiera najważniejsze dla państwa normy ustrojowe. O ustrojowym charakterze normy art. 17 ust. 1 Konstytucji RP przesądził TK m.in. w wyroku z dnia 23 kwietnia 2008 r., SK 16/07, oraz w postanowieniu z dnia 28 lutego 2012 r., SK 27/09; zob. P. Sarnecki, W spra- 
prowadzi do wniosku, że ustawodawca został upoważniony do tworzenia samorządów zawodowych dla zawodów o szczególnym statusie i znaczeniu, określanych „zawodami zaufania publicznego"’. Obowiązująca Konstytucja RP posługuje się tym pojęciem jako pierwsza $z$ polskich ustaw zasadniczych ${ }^{4}$. W żadnym jej miejscu, jak również $\mathrm{w}$ żadnym $\mathrm{z}$ innych obowiązujących aktów prawnych, nie odnajdziemy jego definicji legalnej. Jednocześnie na podstawie dość lakonicznej regulacji ustrojowej nie sposób wskazać na jednoznaczne kryteria pozwalające na kwalifikowanie poszczególnych zawodów do tej kategorii. Okoliczności te sprawiają, że pojęcie to ma charakter niedookreślony, a ustalenie jego znaczenia zostało pozostawione ustawodawcy, do którego należy decyzja o uznaniu poszczególnych profesji za zawody zaufania publicznego i utworzeniu dla nich samorządów zawodowych, orzecznictwu i doktrynie, zwłaszcza prawa publicznego.

Wskazane niejednoznaczności powodują, że wiele środowisk zawodowych ubiegających się o utworzenie dla nich samorządu

wie wykładni art. 17 ust. 1 Konstytucji Rzeczypospolitej Polskiej, „Przegląd Sejmowy" 2001, nr 2, s. 74; M. Szydło, Art. 17, w: Konstytucja RP. Tom I. Komentarz do art. 1-86, red. M. Safjan, L. Bosek, Warszawa 2016, Legalis; B. Banaszak, Konstytucja Rzeczypospolitej Polskiej. Komentarz, Warszawa 2012, Legalis.

${ }^{3}$ Należy zauważyć, że regulacja art. 17 ust. 2 Konstytucji RP przewiduje możliwość tworzenia również innych rodzajów samorządu, nie wyłączając odmiennych niż określone w art. 17 ust. 1 Konstytucji RP samorządów zawodowych. Jak wskazał TK w wyroku z dnia 22 maja 2001 r., K 37/00, w Rzeczypospolitej Polskiej funkcjonować mogą "samorządy zawodowe, reprezentujące osoby wykonujące zawody zaufania publicznego” (ust. 1) oraz „inne rodzaje samorządu” (ust. 2). „Inne rodzaje samorządu” obejmują również, a contrario, „samorządy zawodowe osób niewykonujących zawodów zaufania publicznego”. Jak stwierdził TK w wyroku z dnia 18 lutego 2004 r., P 21/02, ich tworzenie przez ustawodawcę nie może pociągać za sobą ograniczeń zarówno wykonywania zawodu, jak i wolności podejmowania działalności gospodarczej.

${ }_{4}$ Zob. W.J. Wołpiuk, Samorzad zawodu zaufania publicznego a interes publiczny, w: Zawody zaufania publicznego a interes publiczny - korporacyjna reglamentacja versus wolność wykonywania zawodu. Materiały z konferencji zorganizowanej przez Komisję Polityki Społecznej i Zdrowia Senatu RP przy wspótudziale Ministerstwa Pracy i Polityki Społecznej pod patronatem Marszałka Senatu RP Longina Pastusiaka. 8 kwietnia 2002 r., red. S. Legat, M. Lipińska, Warszawa 2002, s. 127-128. 
przedstawia w tym celu różne argumenty, które mają przekonać ustawodawcę do szczególnego statusu ich profesji jako zawodu zaufania publicznego ${ }^{5}$. W ostatnich latach tego rodzaju starania podjęli przedstawiciele zawodów instruktora nauki jazdy i egzaminatora prawa jazdy. Idea społecznej inicjatywy na rzecz ustanowienia wspólnego samorządu tych zawodów została zaprezentowana opinii publicznej w dniu 13 listopada 2018 r. w dokumencie pn. „Deklaracja 13 listopada", a po okresie konsultacji i dyskusji środowiskowych zmaterializowała się w postaci opublikowanej w dniu 27 lipca 2019 r. propozycji projektu ustawy ${ }^{6}$.

W subiektywnej ocenie instruktorów i egzaminatorów ich profesje są zawodami zaufania publicznego ${ }^{7}$. Przedstawione przez nich założenia samorządu zawodowego oraz zaprezentowane w związku z nimi argumenty skłaniają do teoretycznej refleksji nad przesłankami jego utworzenia ${ }^{8}$. W kontekście regulacji ustrojowej podstawowym problemem, który można sformułować na tle tak zdefiniowanego zagadnienia, jest odpowiedź na pytanie: czy zawody instruktora i egzaminatora mają cechy przypisywane zawodom zaufania publicznego? Odpowiedź pozytywna stwarzałaby w dalszej kolejności możliwość utworzenia dla nich samorządu zawodowego w drodze

5 Zob. P. Kłusek, Państwo a samorządy zawodów zaufania publicznego, „Przegląd Prawa i Administracji” 2015, nr 103, s. 77.

6 „Projekt ustawy do konsultacji społecznej przez instruktorów i egzaminatorów o samorządach zawodowych instruktorów, wykładowców i egzaminatorów osób ubiegających się o uprawnienia do kierowania pojazdami oraz instruktorów techniki jazdy osób posiadających uprawnienia do kierowania pojazdami”; http://szie.pl/materialy.zip (dostęp: 10.02.2021 r.).

7 Opublikowana przez inicjatorów utworzenia samorządu zawodowego deklaracja zawiera stwierdzenie: „Instruktorzy nauki jazdy i egzaminatorzy wypełniają szczególną społeczną misję. Wykonują zawód zaufania publicznego", a w dalszej części cytuje treść art. 17 ust. 1 ustawy zasadniczej, co świadczy, że to właśnie ten typ samorządu uznawany jest przez nich za najwłaściwszą formę organizacji własnego środowiska zawodowego; https://www.l-instruktor. pl/szie-deklaracja.html (dostęp: 15.02.2021 r.).

8 Argumenty przemawiające za powołaniem samorządu zawodowego instruktorów i egzaminatorów zostały przedstawione m.in. w dyskusji, która odbyła się podczas 174 posiedzenia Komisji Infrastruktury Senatu RP w dniu 9 lipca 2019 r.; zob. https://www.senat.gov.pl/prace/komisje-senackie/przebieg,8294,1.html (dostęp: 17.02.2021 r.). 
ustawy. Podejmowane w minionych latach przez przedstawicieli innych środowisk zawodowych nieudane próby przeforsowania podobnych rozwiązań ustawowych wskazują jednak, że problematyka kwalifikowania poszczególnych profesji do konstytucyjnej kategorii zawodów, o których mowa w art. 17 ust. 1 Konstytucji RP, stanowi zagadnienie problematyczne dla praktyki ustrojowej i - pomimo przeszło dwóch dekad obowiązywania ustawy zasadniczej - nadal aktualne ${ }^{9}$.

Powyższe dylematy zdeterminowały strukturę artykułu. W pierwszej kolejności przedstawione zostaną pojęcia: samorządu, samorządu zawodowego i zawodu zaufania publicznego. Następnie ogólnej charakterystyce poddane będą regulacje i praktyczne aspekty wykonywania zawodu instruktora oraz egzaminatora w świetle konstytucyjnego pojęcia zawodu zaufania publicznego. Należy przy tym zaznaczyć, że dociekania zawarte w tekście nie mają na celu szczegółowego omówienia i charakterystyki tych zawodów. Taka analiza przekraczałaby ramy niniejszego opracowania. Rozważania będą zatem obejmowały wyłącznie zakres niezbędny do odpowiedzi na postawione pytanie.

\section{Samorząd zawodowy zawodu zaufania publicznego w świetle art. 17 ust. 1 Konstytucji RP}

Na wstępie rozważań dotyczących pojęcia samorządu należy zaznaczyć, że w literaturze można spotkać wiele jego definicji i różne jego ujęcia ${ }^{10}$. Prezentacja dorobku doktryny w tym zakresie wykraczałaby jednak poza ramy niniejszego artykułu. Na potrzeby dalszych rozważań, dla ukazania podstawowych cech tej instytucji, warto zwrócić uwagę na wypowiedź jednego $z$ twórców polskich rozwiązań ustrojowych dotyczących samorządu - Michała Kuleszy. Według niego samorząd stanowi „zdecentralizowaną formę zarządzania

9 Zob. P. Kłusek, Państwo a samorzady, s. 77.

${ }_{10}$ Zob. Z. Leoński, Samorząd terytorialny w RP, Warszawa 2002, s. 5-6. 
sprawami publicznymi, której istota polega na samodzielnym (do granic prawa) i niezależnym (od władzy centralnej) wykonywaniu, przez określoną społeczność, niektórych funkcji z zakresu administracji publicznej, w tym na samodzielnym wykonywaniu przez nią praw korporacyjnych" ${ }^{11}$. Przywołana definicja wydaje się wystarczająca dla przedstawienia istoty samorządu w znaczeniu prawnym. Sprowadza się ona do powierzenia pewnym grupom społecznym i ich reprezentacji realizacji określonych zadań publicznych poprzez wyposażenie ich w tym celu w odpowiednie kompetencje władcze. W ten sposób, w czym zgadzam się ze twierdzeniem Jerzego Stępnia, samorząd wykonuje w określonym zakresie władzę publiczną, stając się jednym z podmiotów tej władzy ${ }^{12}$.

Warto również zwrócić uwagę na poglądy Zbigniewa Leońskiego, który do istotnych cech samorządu zaliczył: korporacyjny charakter, polegający na tym, że przepisy prawa powinny gwarantować określonym grupom społecznym i wyłonionym przez nie organom prawo do zarządzania „swoimi” sprawami; obligatoryjność przynależności, zakładającą, że grupy społeczne zrzeszone w samorządzie przynależą do niego $\mathrm{z}$ mocy samego prawa, a nie na zasadzie dobrowolności; wykonywanie zadań należących do administracji publicznej; realizację zadań na zasadzie samodzielności, co oznacza, że wkraczanie w formie nadzoru w działalność samorządu może następować wyłącznie w formach określonych w ustawie i w sposób nienaruszający jego autonomii. Według Leońskiego w zależności od kryterium więzi łączącej członków samorządu można wyróżnić następujące jego typy: samorząd terytorialny - oparty na więzi terytorialnej, samorząd gospodarczy - oparty na więzi gospodarczej, oraz samorząd zawodowy - oparty na więzi wynikającej z wykonywanego zawodu ${ }^{13}$.

${ }^{11}$ M. Kulesza, Samorzą, w: Stownik społeczny, red. B. Szlachta, Kraków 2004, s. 1153; por. K. Bandarzewski, Samorzad gospodarczy w prawie polskim. Studium prawne, Kraków 2014, s. 69-78.

12 Zob. J. Stępień, Dyskusja, w: Zawody zaufania publicznego a interes publiczny, s. 92.

${ }^{13}$ Zob. Z. Leoński, Samorząd terytorialny, s. 6; por. I. Szymczak, Funkcje ustrojowe oraz zadania zawodowe samorządu notarialnego (rozważania prawnoporównawcze), „Rejent” 1997, nr 10, s. 98. 
Samorząd zawodowy określa się jako „organizacyjną formę zrzeszania się osób wykonujących ten sam zawód, której celem jest m.in. reprezentowanie ich interesów wobec władz państwowych, doskonalenie zawodowe i czuwanie nad etyką wykonywania zawodu oraz ochrona socjalna tych osób, a także realizowanie szeregu zadań typowych dla związków publicznoprawnych"14. Przywołana definicja odwołuje się do cech samorządu, którego prawne umocowanie znalazło swoje miejsce w art. 17 ust. 1 ustawy zasadniczej. Jak wspomniałem na wstępie, możliwość utworzenia samorządu zawodowego została przewidziana w tym przepisie Konstytucji RP wyłącznie dla grup osób wykonujących zawody zaufania publicznego. Ustalenie znaczenia tego pojęcia, co było już sygnalizowane, nie stanowi łatwego zadania, a wydaje się istotne dla zakwalifikowania poszczególnych zawodów do tej kategorii. Mając na względzie brak jego prawnej definicji, należy podjąć próbę jego określenia na podstawie refleksji zawartych $\mathrm{w}$ nauce i orzecznictwie.

W doktrynie prawa konstytucyjnego warto zwrócić przede wszystkim uwagę na poglądy wyrażone przez Pawła Sarneckiego, który poświęcił wiele miejsca w swoim dorobku naukowym zagadnieniom związanym z samorządami zawodowymi i ich konstytucyjnym statusem. Jeszcze przed uchwaleniem obecnie obowiązującej ustawy zasadniczej i ukuciem w toku prac nad nią pojęcia zawodu zaufania publicznego autor ten wyraził przekonanie, że powołanie samorządu zawodowego znajduje swoje uzasadnienie wówczas, gdy określony zawód ma istotne znaczenie publiczne, właściwym jego wykonywaniem zainteresowana jest całość społeczeństwa, wymaga on przestrzegania pewnych cech etyczno-zawodowych, a ponadto celowe jest zapewnienie jego przedstawicielom pewnej niezależności ${ }^{15}$. Poglądy te nie utraciły na aktualności pomimo przyjęcia w 1997 r. nowego modelu samorządu zawodowego. W rozumieniu uchwalonej wówczas Konstytucji RP zawód zaufania publicznego,

${ }^{14}$ R. Kmieciak, Samorząd gospodarczy w Polsce. Rozważania na temat modelu ustrojowego, Poznań 2004, s. 66-67; por. H. Zięba-Załucka, Samorząd zawodowy w świetle Konstytucji RP, „Monitor Prawniczy” 2005, nr 10, s. 493.

15 Zob. P. Sarnecki, Opinia o projekcie ustawy „Prawo o adwokaturze”, „Palestra” 1991, nr 1-2, s. 89-90. 
zdaniem Pawła Sarneckiego, cechuje przede wszystkim „spełnianie pewnej funkcji publicznej”, które charakteryzuje „szczególne natężenie", polegające na tym, że jego wykonywanie ma znaczenie dla „zapewnienia właściwego biegu całego życia społecznego”. Wobec tego $\mathrm{w}$ społeczeństwie powinno istnieć zaufanie do jego prawidłowego wykonywania analogiczne do zaufania wobec organów państwowych. Co więcej, korzystanie z usług przedstawicieli takiego zawodu wiąże się na ogół $z$ powierzaniem im informacji o charakterze osobistym, objętych tajemnicą zawodową, której są oni obowiązani dochować. Wymóg ten określany jest często przepisami prawa oraz kodeksami etyki zawodowej, których przestrzeganie jest powinnością członków samorządu zawodowego. Wymagania te determinują nadzwyczaj wysokie bariery dostępu do zawodu, obejmujące najczęściej wymóg ukończenia specjalistycznego szkolenia, jak również posiadania odpowiedniego poziomu etycznego kandydatów do zawodu, zapewniającego rękojmię należytego jego wykonywania. W związku $z$ tymi cechami samorząd zawodowy zawodu zaufania publicznego musi być wyposażony w szerszy niż w innych formach samorządu nieterytorialnego zakres władztwa publicznego, pozwalający na sprawowanie kontroli nad przestrzeganiem zasad wykonywania zawodu przez jego członków oraz stosowanie odpowiednich sankcji wobec ich naruszania. Ponadto szczególną cechą samorządu zawodu zaufania publicznego, w odróżnieniu od typowych przymiotów samorządu gospodarczego, jest swoiste traktowanie działalności zarobkowej jego członków, które nie może koncentrować się przede wszystkim na osiąganiu jak najwyższych dochodów z działalności zawodowej, co nie wyłącza uzyskiwania stosownych korzyści finansowych $z$ jej prowadzenia ${ }^{16}$.

Powyższa charakterystyka pozwala na zdefiniowanie zawodu zaufania publicznego poprzez ukazanie cech tego typu profesji. Warto także zaprezentować inne od przedstawionego ujęcie. Według cytowanego już Michała Kuleszy pomimo podejmowanych w doktrynie i orzecznictwie prób zdefiniowania pojęcia zawodu zaufania publicznego, zwłaszcza poprzez pokazanie cech takiego

${ }^{16}$ Zob. P. Sarnecki, W sprawie, s. 75-76. 
zawodu w opozycji do cech innych, nieposiadających takiego przymiotu zawodów, nie da się zbudować jego merytorycznej definicji. Nie istnieje również katalog zawodów zaufania publicznego, gdyż każdy zawód wymaga zaufania publicznego, a ta szczególna kategoria konstytucyjna „odnosi się nie tyle do samego zawodu, jego cech, ile do stanu czy też stopnia jego zorganizowania”17. Istotne znaczenie przypisał zatem Kulesza prezentowanemu przez dane środowisko poziomowi deontologicznemu, trwałości zorganizowania grupy zawodowej w sensie społecznym i tradycyjnym, pozwalającej na powierzenie jej władztwa publicznego „w granicach interesu publicznego i dla jego ochrony”. Wobec tego decyzję o powołaniu samorządu zawodowego powinno poprzedzić badanie przez ustawodawcę, czy określoną grupę można obdarzyć zaufaniem publicznym i czy ona jest je w stanie „udźwignąć”. Należy nadmienić, że według Michała Kuleszy pojęcie samorządu zawodowego w świetle art. 17 ust. 1 Konstytucji RP odnosi się tradycyjnie do tzw. wolnych zawodów ${ }^{18}$, wykonywanych przede wszystkim na własny rachunek, a dla pozostałych profesji właściwą formę zrzeszania się stanowi samorząd gospodarczy ${ }^{19}$.

Pojęcie zawodu zaufania publicznego można próbować ustalić również w świetle orzecznictwa Trybunału Konstytucyjnego, który zabierał głos w tej sprawie wielokrotnie ${ }^{20}$. Wnioski z tych rozważań zostały zaprezentowane m.in. w wyroku z dnia 24 marca 2015 r., w którym Trybunał uznał, że za powołaniem samorządu zawodowego danej profesji przemawiają następujące okoliczności:

- konieczność zapewnienia prawidłowego i zgodnego $z$ interesem publicznym wykonywania zawodu ze względu na znaczenie, jakie dana dziedzina aktywności zawodowej ma w społeczeństwie;

17 M. Kulesza, Pojęcie zawodu, s. 29.

18 Na temat pojęcia wolnego zawodu zob. K. Wojtczak, Zawód i jego prawna reglamentacja. Studium z zakresu materialnego prawa administracyjnego, Poznań 1999, s. 111-112.

19 Zob. M. Kulesza, Pojęcie zawodu, s. 25-29.

20 Zob. wyroki TK: $z$ dnia 7 marca 2012 r., K 3/10; z dnia 26 marca 2008 r., K 4/07; z dnia 2 lipca 2007 r., K 41/05; z dnia 8 listopada 2006 r., K 30/06; z dnia 22 maja 2001 r., K 37/00. 
- udzielanie świadczeń i wchodzenie przez przedstawicieli zawodu w kontakty $\mathrm{z}$ osobami fizycznymi w razie wystąpienia potencjalnego lub realnego zagrożenia dóbr o szczególnym charakterze, np. życia, zdrowia, wolności, godności, dobrego imienia;

- staranność i dbałość przedstawicieli zawodu o interesy osób korzystających $z$ jego usług, troska o ich osobiste potrzeby, a także zapewnienie ochrony gwarantowanych przez Konstytucję praw podmiotowych jednostek;

- wymaganie szczególnych kwalifikacji do wykonywania zawodu, obejmujących nie tylko odpowiednie, formalne wykształcenie, ale także nabyte doświadczenie oraz dawanie rękojmi należytego i zgodnego $z$ interesem publicznym jego wykonywania, $z$ uwzględnieniem szczególnych norm deontologii zawodowej;

- pozyskiwanie informacji osobistych i dotyczących życia prywatnego osób korzystających $z$ usług przedstawicieli zawodu zaufania publicznego, które stanowią tajemnicę zawodową;

- względna samodzielność wykonywania zawodu ${ }^{21}$.

Na tle przedstawionych poglądów można podjąć próbę odkodowania najważniejszych wymagań stawianych przed zawodami charakteryzującymi się przymiotem zaufania publicznego. Wydaje się, że pojęcie to odnosi się przede wszystkim do profesji, których wykonywanie wiąże się $\mathrm{z}$ realizowaniem istotnych $\mathrm{w}$ wymiarze publicznym czynności zawodowych, wymagających szczególnego rodzaju zaufania $^{22}$, i to co najmniej w dwóch wymiarach, tj. zaufania na linii samorząd zawodowy-społeczeństwo oraz zaufania indywidualnego, na linii osoba wykonująca zawód-klient. $Z$ tego rodzaju zawodami wiążą się szczególne oczekiwania społeczne, których treść determi-

${ }^{21}$ Zob. wyrok TK z dnia 24 marca 2015 r., K 19/14.

${ }^{22}$ W opinii TK zawartej w wyroku z dnia 18 lutego 2004 r., P 21/02, „zawody zaufania publicznego" wykonywane są - zgodnie $z$ ich konstytucyjnym określeniem - w sposób założony i społecznie aprobowany, o ile ich wykonywaniu towarzyszy realne „zaufanie publiczne”. Na zaufanie to składa się przede wszystkim przekonanie o zachowaniu przez wykonującego ten zawód dobrej woli, właściwych motywacji, należytej staranności zawodowej oraz wiara $\mathrm{w}$ przestrzeganie wartości istotnych dla profilu danego zawodu. 
nuje charakter dóbr o istotnym dla każdego człowieka znaczeniu, których ochronę zapewniają osoby je wykonujące, a także udzielanych im prywatnych informacji, objętych $z$ tego tytułu prawnie i deontologicznie chronioną tajemnicą zawodową. Gwarancję prawidłowości ich wykonywania stanowią wysokie wymogi ograniczające dostęp do zawodu, określone koniecznością posiadania szczególnych kwalifikacji, odbycia specjalistycznych szkoleń, złożenia egzaminów, a także prezentowania odpowiedniego poziomu etycznego. Oczekiwaniem społecznym jest, aby samorząd zawodowy tworzyły osoby cechujące się wysoką wiedzą merytoryczną oraz predyspozycjami natury moralnej ${ }^{23}$. Istotna w tym kontekście jest kontrola samorządu zawodowego nad prawidłowym wykonywaniem zawodu przez jego członków, pozwalająca na efektywne egzekwowanie staranności zawodowej oraz przestrzegania etyki zawodowej. Wymaga to wysokiego stopnia samoorganizacji osób wykonujących takie zawody, a także wyposażenia samorządu zawodowego w odpowiednie kompetencje władcze.

Regulacja konstytucyjna samorządów zawodowych zawodów zaufania publicznego wiąże $z$ ich działalnością realizację dwóch ustrojowych funkcji. Po pierwsze, jest to zadanie reprezentowania osób wykonujących zawód wobec obywateli, ich organizacji oraz organów państwa ${ }^{24}$. Po drugie, jest to sprawowanie pieczy nad należytym wykonywaniem zawodu, zawsze jednak w granicach interesu publicznego i dla jego ochrony. W doktrynie oraz orzecznictwie podkreśla się, że pieczę samorządu zawodowego nad należytym wykonywaniem zawodu należy rozumieć szeroko ${ }^{25}$. Składa się na nią suma działań podejmowanych przez samorząd zawodowy, których

${ }^{23}$ Zgodnie $z$ komunikatem $z$ badań przeprowadzonych przez Centrum Badania Opinii Społecznej pojęcie zawodu zaufania publicznego kojarzy się Polakom przede wszystkim z pracą wymagającą od wykonujących ją osób specjalnych standardów etycznych, moralnych oraz wysokiej jakości usług. Zob. Centrum Badania Opinii Społecznej, Opinia społeczna na temat zawodów zaufania publicznego. Komunikat $z$ badań, Warszawa 2004, s. 2.

${ }^{24}$ Zob. wyrok TK z dnia 22 maja 2001 r., K 37/00.

${ }^{25}$ Zob. wyrok TK z dnia 14 grudnia 2010 r., K 20/02; H. Izdebski, Sprawowanie pieczy nad należytym wykonywaniem zawodu przez samorzady zawodowe, w: Zawody zaufania publicznego a interes publiczny, s. 35. 
cel i granice wyznacza przesłanka interesu publicznego, a jej zakres przedmiotowy określa termin "należyte wykonywanie zawodu”26. Szczegółowe wskazanie zadań samorządu składających się na pieczę nad należytym wykonywaniem zawodu należy do ustawodawcy ${ }^{27}$.

\section{Zawody instruktora nauki jazdy i egzaminatora prawa jazdy w świetle pojęcia zawodu zaufania publicznego}

Przechodząc do ustalenia, czy zawody instruktora ${ }^{28}$ i egzaminatora mają cechy charakterystyczne zawodów zaufania publicznego,

${ }^{26}$ Zob. wyrok NSA z dnia 5 kwietnia 2013 r., II GSK 2332/11; w orzecznictwie TK pod pojęciem pieczy rozumiano m.in.: reglamentowanie dostępu do wykonywania zawodu, ustalanie zasad etyki zawodowej oraz jej egzekwowanie, sprawowanie sądownictwa dyscyplinarnego, prowadzenie listy osób uprawnionych do wykonywania zawodu, organizowanie doskonalenia zawodowego, określanie zasad przygotowania do wykonywania zawodu i współuczestnictwo $\mathrm{w}$ procesie potwierdzania uprawnień, kontrolowanie sposobu wykonywania zawodu oraz wykonywanie zadań technicznych i organizacyjnych związanych z funkcjonowaniem samorządu zawodowego i realizacją zadań; zob. wyroki TK: z dnia 22 maja 2001 r., K 37/00; z dnia 18 lutego 2004 r., P 21/02; z dnia 19 kwietnia 2006 r., K 6/06; z dnia 8 listopada 2006 r., K 30/06; z dnia 1 grudnia 2009 r., K 4/08; z dnia 18 października 2010 r., K 1/09; z dnia 14 grudnia 2010 r., K 20/08; z dnia 30 listopada 2011 r., K 1/10; z dnia 6 marca 2012 r., K 15/08; z dnia 25 lipca 2012 r., K 14/10.

27 TK w wyroku $z$ dnia 8 listopada 2006 r., K 30/06, uznał, że swoboda ustawodawcy nie jest jednak w tym zakresie nieograniczona. Na temat ewolucji poglądów Trybunału w kwestii granic konstytucyjnej pieczy samorządów zawodowych nad należytym wykonywaniem zawodu zob. M. Jackowski, Ewolucja konstytucyjnego pojęcia pieczy $w$ orzecznictwie Trybunału Konstytucyjnego, „Palestra” 2013, nr 11-12.

${ }^{28}$ Obok zawodu instruktora u.o.k.p. mówi jeszcze o zawodzie wykładowcy oraz instruktora techniki jazdy. Różnica pomiędzy zawodami instruktora nauki jazdy i wykładowcy polega na zakresie uprawnień - instruktor uprawniony jest do prowadzenia zajęć teoretycznych i praktycznych, wykładowca prowadzi zajęcia wyłącznie teoretyczne. Odrębną kategorię stanowią instruktorzy techniki jazdy, których zadaniem jest prowadzenie zajęć w ośrodku doskonalenia techniki jazdy. Zob. S. Soboń, Kodeks drogowy. Komentarz z orzecznictwem NSA, 
a w konsekwencji, czy właściwą formę ich organizacji stanowi samorząd zawodowy, o którym mowa w art. 17 ust. 1 Konstytucji RP, należy odnieść się przede wszystkim do regulacji prawnej tych zawodów, która została zawarta w przepisach Ustawy z dnia 5 stycznia 2011 r. o kierujących pojazdami ${ }^{29}$ (dalej: u.o.k.p.), a także pewnych faktów, które dotyczą ich wykonywania w praktyce ${ }^{30}$.

W pierwszej kolejności należy rozważyć, czy z wykonywaniem zawodów instruktora i egzaminatora wiąże się świadczenie istotnych w wymiarze publicznym czynności zawodowych, wymagających szczególnego rodzaju zaufania do osób je wykonujących oraz ich środowiska zawodowego. $Z$ całą pewnością trzeba docenić znaczenie tych zawodów w kontekście wartości, jaką w życiu społecznym stanowią uprawnienia do kierowania pojazdami mechanicznymi, których uzyskanie wiąże się z ukończeniem odpowiedniego szkolenia oraz zdaniem egzaminu państwowego. Prawo jazdy jest obecnie dokumentem niemal powszechnym. Poziom przygotowania teoretycznego i praktycznego przyszłych kierowców, a także jakość systemu egzaminowania nie pozostają bez wpływu na bezpieczeństwo ruchu drogowego, które dotyczy wszystkich użytkowników dróg ${ }^{31}$. W tym kontekście rola instruktora i egzaminatora w procesie zdobywania uprawnień do kierowania pojazdami wydaje się na tyle istotna,

SN i TK. Część III. Ustawa o kierujących pojazdami z komentarzem, Warszawa 2014, s. 129-130, 319-321.

${ }^{29}$ Dz.U. Nr 30, poz. 151; tekst jednolity: Dz.U. z 2020 r. poz. 1268.

${ }^{30} \mathrm{~W}$ tym zakresie posługuję się przede wszystkim własnymi obserwacjami, jako osoby zatrudnionej od 2015 r. na stanowisku zastępcy dyrektora w wojewódzkim ośrodku ruchu drogowego, odpowiedzialnej m.in. za nadzór nad pracą egzaminatorów i współpracę z ośrodkami szkolenia kierowców.

${ }^{31}$ Należy zwrócić uwagę, że zgodnie $z$ informacjami zawartymi w „Narodowym Programie Bezpieczeństwa Ruchu Drogowego 2013-2020” oraz publikowanych corocznie raportach Krajowej Rady Bezpieczeństwa Ruchu Drogowego prezentujących stan bezpieczeństwa ruchu drogowego w poszczególnych latach, pomimo podejmowanych działań na rzecz poprawy bezpieczeństwa ruchu drogowego, Polska jest w grupie państw, w których prawdopodobieństwo śmierci bądź odniesienia obrażeń przez uczestników ruchu drogowego należy do najwyższych w Unii Europejskiej. Zob. https://www.krbrd.gov.pl/programy-brd/ /narodowy-program-brd/ (dostęp: 16.02.2021 r.); https://www.krbrd.gov.pl/ /baza-wiedzy/raporty-o-stanie-brd/ (dostęp: 16.02.2021 r.). 
że $\mathrm{z}$ całą pewnością istnieniem wykwalifikowanej i profesjonalnej kadry instruktorskiej i egzaminatorskiej zainteresowane jest całe społeczeństwo. Należy jednak podnieść wątpliwość, czy z wykonywaniem tych zawodów wiąże się szczególny, ponadprzeciętny stopień zaufania publicznego, który społeczeństwo żywi indywidualnie do ich przedstawicieli oraz do całej grupy zawodowej, odpowiadający natężeniu, jakie przybierać powinno zaufanie do organów państwowych $^{32}$. Obiekcję tę wzmacnia okoliczność, że w świetle u.o.k.p., jak również biorąc pod uwagę praktykę wykonywania tych zawodów, trudno uznać, że praca instruktora i egzaminatora wiąże się z przetwarzaniem szczególnego rodzaju informacji o charakterze prywatnym czy osobistym, których ochrona wymagałaby zachowania tajemnicy zawodowej. W związku z tym nie sposób również mówić o stosowaniu jakichkolwiek mechanizmów, czy to prawnych, czy deontologicznych, służących ich zabezpieczeniu. Brak ten nieco równoważy istotny charakter dóbr, jakimi są zdrowie i życie uczestników ruchu drogowego, $z$ których ochroną wiąże się wykonywanie tych zawodów.

Ustawodawca w sposób zróżnicowany określił bariery dostępu do przedmiotowych zawodów. Zwraca szczególnie uwagę, że z podjęciem pracy $\mathrm{w}$ zawodzie instruktora nie jest związany obowiązek posiadania określonego rodzaju wykształcenia ${ }^{33}$. Musi to dziwić w kontekście klasyfikowania go jako profesji nauczycielskiej i łączącej się z szeroko pojętą edukacją ${ }^{34}$. Od kandydata na instruk-

32 Zob. w szczególności informację Najwyższej Izby Kontroli o wynikach kontroli prawidłowości szkolenia i egzaminowania kandydatów na kierowców oraz wydawania praw jazdy i zawarte w niej wnioski dotyczące jakości szkolenia i egzaminowania kandydatów na kierowców: https://www.nik.gov.pl/kontrole/ /wyniki-kontroli-nik/pobierz,px_2001192.pdf,typ,k.pdf (dostęp: 19.02.2021 r.).

${ }^{33}$ Wymóg dotyczący posiadania wykształcenia średniego przez instruktora nauki jazdy został zniesiony nowelizacją u.o.k.p., dokonaną przez Ustawę $z$ dnia 13 czerwca 2013 r. o zmianie ustaw regulujących wykonywanie niektórych zawodów (Dz.U. poz. 829), ujętą w obwieszczeniu Marszałka Sejmu Rzeczypospolitej Polskiej z dnia 12 marca 2014 r. w sprawie ogłoszenia jednolitego tekstu ustawy o kierujących pojazdami (Dz.U. poz. 600).

${ }^{34}$ Zob. Ministerstwo Rodziny, Pracy i Polityki Społecznej, Departament Rynku Pracy, Informacja o zawodzie. Instruktor nauki jazdy (516502), Warszawa 2018, s. 3. 
tora wymaga się, zgodnie $z$ art. 33 ust. 1 u.o.k.p., posiadania prawa jazdy przez oznaczony dla danej kategorii okres, ukończenia z wynikiem pozytywnym kursu przygotowującego do wykonywania zawodu oraz zdania egzaminu sprawdzającego kwalifikacje przed komisją egzaminacyjną powołaną przez wojewodę ${ }^{35}$. Na tym tle wyróżniają się kryteria stawiane wobec kandydata na egzaminatora. Zgodnie $z$ art. 58 u.o.k.p. egzaminatorem może być osoba, która zdobyła co najmniej wykształcenie średnie lub średnie branżowe, posiada przez okres co najmniej trzech lat prawo jazdy kategorii B oraz przez okres co najmniej roku prawo jazdy odpowiednio do zakresu przeprowadzanego egzaminu ${ }^{36}$, ma powyżej 23 lat, ukończyła z wynikiem pozytywnym kurs kwalifikacyjny oraz złożyła egzamin przed komisją weryfikacyjną powołaną przez ministra właściwego do spraw transportu. Podkreślenia wymaga, że wobec egzaminatora ustawodawca określił szczególnego rodzaju obwarowanie, charakterystyczne dla wymogów stawianych wobec przedstawicieli wielu zawodów zaufania publicznego, w postaci dawania rękojmi należytego wykonywania obowiązków, co wiąże się z oceną cech charakteru i dotychczasowego postępowania w sferze zawodowej i prywatnej ${ }^{37}$. Należy również zwrócić uwagę, że egzaminator, jako

35 Mniejsze wymagania ustawodawca postawił przed kandydatami na wykładowców, od których, zgodnie $z$ art. 38 ust. 1 u.o.k.p., wymaga się posiadania zaświadczenia o ukończeniu $z$ wynikiem pozytywnym kursu dla kandydatów na instruktorów lub wykładowców oraz złożenia $z$ wynikiem pozytywnym egzaminu sprawdzającego kwalifikacje przed komisją egzaminacyjną powołaną przez wojewodę. Inaczej ukształtowane zostały wymagania wobec instruktorów techniki jazdy. Zgodnie $z$ art. 117 ust. 1 u.o.k.p. wymaga się od nich posiadania co najmniej wykształcenia średniego lub średniego branżowego, posiadania co najmniej przez okres trzech lat prawa jazdy kategorii B oraz co najmniej przez okres roku prawa jazdy kategorii odpowiedniej do zakresu prowadzonych zajęć, ukończenia kursu dla osób ubiegających się o uprawnienia instruktora techniki jazdy oraz złożenia $z$ wynikiem pozytywnym egzaminu $z$ wiedzy teoretycznej i umiejętności praktycznych przed komisją egzaminacyjną powołaną przez ministra właściwego do spraw transportu.

${ }^{36} \mathrm{~W}$ przypadku osoby ubiegającej się o uprawnienia do egzaminowania na pozostałe kategorie prawa jazdy, zgodnie $z$ art. 58 ust. 1 pkt. 3 u.o.k.p., istnieje wymóg posiadania uprawnienia egzaminatora w zakresie prawa jazdy kategorii B od co najmniej trzech lat.

${ }^{37}$ Zob. wyroki NSA: z dnia 18 sierpnia 1994 r., II SA 860/93; z dnia 17 kwiet- 
podmiot realizujący istotne zadanie publiczne w postaci sprawdzania umiejętności kandydatów na kierowców i kierowców, podczas przeprowadzania egzaminu państwowego na prawo jazdy podlega ochronie przysługującej funkcjonariuszowi publicznemu (art. 63 ust. 2 u.o.k.p.).

Wykonywanie zawodu zaufania publicznego wymaga przestrzegania określonych standardów etycznych i zawodowych. Potrzeba regulacji deontologii zawodowej została dostrzeżona przez środowiska instruktorów i egzaminatorów na długo przed rozpoczęciem dyskusji o powołaniu samorządu zawodowego ${ }^{38}$. Zasady etycznego postępowania instruktorów zostały skodyfikowane w postaci przyjętego w 2014 r., po wielu latach od jego opracowania ${ }^{39}$, „Kodeksu etycznego instruktora nauki jazdy"40. Dwa lata wcześniej, w 2012 r., regulację etyczną pn. „Kodeks etyki zawodowej OIGOSK”, uchwaliła Ogólnopolska Izba Gospodarcza Ośrodków Szkolenia Kierowców ${ }^{41}$. Zawiera ona m.in. powinności dotyczące instruktorów. Wobec tego należy odnotować, że istnieją co najmniej dwa kodeksy dotyczące tej samej grupy zawodowej, przez co żaden $z$ nich nie stanowi aktu o powszechnym charakterze. Kodyfikację etyczną mają również egzaminatorzy. Została ona przyjęta przez Krajowe Stowarzyszenie

nia 1991 r., II SA 75/91; z dnia 5 kwietnia 2001 r., II SA 725/00; z dnia 18 czerwca 2001 r., II SA 1610/00.

38 Zob. Z. Ożdżyński, Etyka i edukacja a bezpieczeństwo ruchu drogowego, „Przedsiębiorczość - Edukacja” 2008, t. 4, s. 302-310; P. Żuraw, Etyka jako narzędzie wspomagające zarządzanie ośrodkiem szkolenia kierowców, „Logistyka" 2012, nr 3.

${ }^{39}$ Projekt kodeksu został zredagowany przez Instytut Transportu Samochodowego $z$ udziałem instruktorów i wykładowców nauki jazdy na 10 lat przed jego przyjęciem; zob. https://www.l-instruktor.pl/aktualnosci/kodeks-etyczny-instruktora.html\#.YCzUi3ndiUk (dostęp: 17.02.2021 r.).

${ }^{40}$ Zob. P. Żuraw, Etyczne determinanty zarzadzania ośrodkami szkolenia kierowców $w$ świetle zmian prawnych obowiazujących od 2013 r., „Annales. Etyka w życiu gospodarczym" 2014, nr 2, s. 85-96; https://www.szkola-jazdy.pl/kodeks-etyczny-instruktora-nauki-jazdy-cz-1/ (dostęp: 17.02.2021 r.); https://www.szkola-jazdy.pl/kodeks-etyczny-instruktora-nauki-jazdy-cz-2/ (dostęp: 17.02.2021 r.).

${ }^{41}$ http://www.izbaosk.eu/index.php/regulaminy/155-kodeks-etyki-zawodowej-oigosk (dostęp: 17.02.2021 r.). 
Egzaminatorów Kandydatów na Kierowców i Kierowców (dalej: KSE), w postaci Kodeksu etycznego egzaminatora ${ }^{42}$. Niezależnie od tego egzaminatorzy jako osoby zatrudnione w wojewódzkich ośrodkach ruchu drogowego podlegają również regulacjom kodeksów etyki pracowników tych instytucji ${ }^{43}$. Ujawnia to problem tzw. podwójnej deontologii, czyli obowiązywania więcej niż jednego zestawu potencjalnie sprzecznych reguł etycznych.

Wspólną cechą wszystkich wymienionych regulacji etycznych jest wysoka troska o standardy zawodowe, istotne jest jednak urzeczywistnianie tych zasad i ich egzekwowanie, którym nie sprzyja duże rozproszenie środowiska instruktorskiego w różnego rodzaju stowarzyszeniach, fundacjach i klastrach, duża liczba instruktorów pozostających poza przynależnością do jakichkolwiek organizacji, a także brak powszechnej przynależności egzaminatorów do KSE, stanowiącego ważną organizację zawodową tego środowiska w Polsce $^{44}$. Podsumowując tę część rozważań, należy uznać, że pomimo wypracowania i skodyfikowania etycznych standardów postępowania wątpliwości musi budzić brak powszechnego ich stosowania oraz skutecznych mechanizmów ich egzekwowania. Dostrzec należy także niepodjęcie dotychczas próby określenia wspólnych dla instruktorów i egzaminatorów wartości, co wiąże się z niskim stopniem wewnętrznego zorganizowania i wzajemnej integracji tych środowisk ${ }^{45}$.

42 Zob. P. Żuraw, Kodeks etyczny egzaminatora, „Szkoła Jazdy” 2011, nr 6, s. 32 .

${ }^{43}$ Jako przykłady tego typu regulacji można wymienić: „Kodeks etyki pracownika Wojewódzkiego Ośrodka Ruchu Drogowego w Kielcach”, „Kodeks etyczny pracowników Wojewódzkiego Ośrodka Ruchu Drogowego - Regionalnego Centrum Bezpieczeństwa Ruchu Drogowego w Olsztynie” czy „Kodeks etyki pracownika Wojewódzkiego Ośrodka Ruchu Drogowego w Białej Podlaskiej”.

${ }^{44}$ Na temat działalności KSE zob. https://kse-egzaminator.pl/ (dostęp: 17.02. 2021 r.).

45 Na tle dyskusji o powołaniu samorządu zawodowego ujawniły się pewne podziały wewnątrz środowiska instruktorskiego, które świadczą o tym, że nie „mówi ono jednym głosem”. Zob. chociażby: Z. Muszyński, Stowarzyszenie czy samorząd?, „Bezpieczny Kierowca” 2019, nr 7, s. 16-17; Ł. Szewczyk, Samorządy i federacje, „Szkoła Jazdy” 2019, nr 2, s. 14. 
Podstawowe standardy profesjonalnego wykonywania zawodów instruktora i egzaminatora wyznacza u.o.k.p. Przepisy zobowiązują ich przedstawicieli do wysokiej staranności zawodowej poprzez wymóg rzetelnego i bezstronnego wykonywania swoich obowiązków oraz poszerzania wiedzy i podnoszenia kwalifikacji. Służy temu obowiązek corocznego doskonalenia zawodowego w postaci uczestnictwa w organizowanych w tym celu warsztatach, których odbycie warunkuje możliwość pracy w zawodzie. Ponadto przepis art. 63 ust. 3 u.o.k.p. ustanawia dodatkowe gwarancje bezstronności egzaminatora, na które składają się: zakaz podejmowania zajęć zarobkowych bez zgody dyrektora wojewódzkiego ośrodka ruchu drogowego, zakaz prowadzenia szkoleń dla osób ubiegających się o uzyskanie uprawnienia do kierowania pojazdami, a także obowiązek unikania konfliktu interesów w postaci zakazu przeprowadzania egzaminów wobec osób pozostających $z$ egzaminatorem w określonych ustawą stosunkach lub szkolonych przez takie osoby. Egzaminator został również, zgodnie $z$ art. 63 ust. 5 u.o.k.p., zobowiązany do składania oświadczenia majątkowego ${ }^{46}$. Należy nadmienić, że wobec osób wykonujących analizowane zawody ustawa stawia wymóg niekaralności za określone w niej przestępstwa ${ }^{47}$.

\section{Wnioski}

Przystępując na tle powyższych rozważań do próby odpowiedzi na pytanie, czy zawody instruktora i egzaminatora należy uznać za zawody zaufania publicznego w konstytucyjnym ujęciu, a w kon-

\footnotetext{
46 Przepis ten stanowi: „Do egzaminatora zatrudnionego w wojewódzkim ośrodku ruchu drogowego stosuje się przepisy art. 4 , art. 5 ust. 1 pkt 1, art. 8 ust. 1 , art. 10 ust. 1,3 i 4 oraz art. 14 ustawy z dnia 21 sierpnia 1997 r. o ograniczeniu prowadzenia działalności gospodarczej przez osoby pełniące funkcje publiczne (Dz.U. z 2019 r. poz. 2399)”.

47 Ustawa wymienia w tym zakresie przestępstwa: przeciwko bezpieczeństwu w komunikacji; popełnione w celu osiągnięcia korzyści majątkowej lub osobistej; przeciwko wiarygodności dokumentów; prowadzenie pojazdu w stanie po użyciu alkoholu lub po użyciu innego podobnie działającego środka; umyślne przeciwko życiu i zdrowiu; przeciwko wolności seksualnej i obyczajności.
} 
sekwencji, czy osoby wykonujące te zawody powinny zostać objęte konstrukcją samorządu zawodowego, należy przy formułowaniu jednoznacznych wniosków zachować daleko idącą ostrożność. Przede wszystkim trzeba podkreślić wysokie znaczenie społeczne i wartość tych zawodów. Istnieją jednak poważne wątpliwości, czy stanowią one profesje o odpowiednio doniosłym znaczeniu publicznym. Co istotne, $z$ wykonywaniem wymienionych zawodów nie jest związany obowiązek dochowania tajemnicy zawodowej, a nawet przetwarzania istotnych danych o charakterze prywatnym lub osobistym. Należy ponadto dostrzec różnice pomiędzy regulacją zawodu instruktora i egzaminatora. Zwracają uwagę nieszczególnie wysokie bariery dostępu do tego pierwszego zawodu, a zwłaszcza brak obowiązku posiadania przez osoby go wykonujące chociażby średniego wykształcenia, co na skutek decyzji związanych z tzw. deregulacją zawodów niewątpliwie obniżyło jego prestiż. Zdecydowanie lepiej pod tym względem należy ocenić regulację ustawową zawodu egzaminatora. Wynika $z$ niej obowiązek dawania rękojmi prawidłowego wykonywania zawodu przez jego przedstawicieli oraz ochrona przewidziana dla funkcjonariusza publicznego, która przysługuje egzaminatorowi, w trakcie przeprowadzania egzaminu państwowego na prawo jazdy. $Z$ tych powodów zawód ten należy uznać za bardziej doniosły społecznie i mający pewne cechy charakterystyczne zawodu zaufania publicznego. Dostrzegalny jest także niski stopień samoorganizacji środowiska instruktorskiego i egzaminatorskiego, który przejawia się w braku wspólnych i powszechnych struktur zdolnych do przejęcia roli organów samorządu zawodowego, a także oddziałujących na osoby wykonujące te zawody, zwłaszcza poprzez promocję przestrzegania wspólnych wartości etycznych, a także podejmowanie działań na rzecz wzmacniania wzajemnych więzi.

Zgodnie $z$ literalnym brzmieniem art. 17 ust. 1 Konstytucji RP nie wszystkie zawody zaufania publicznego muszą być zorganizowane w formie samorządów zawodowych, na co wskazuje posłużenie się w treści tego przepisu czasownikiem „można”. Ponadto nie wszystkie zawody, do których wykonywania niezbędne jest zaufanie społeczne, są zawodami zaufania publicznego w konstytucyjnym rozumieniu. Dla zawodów nieposiadających tego przymiotu właściwą formą organizowania się pozostaje samorząd gospodarczy lub inne 
zrzeszenie, np. stowarzyszenie zawodowe ${ }^{48}$. Wymienione struktury wydają się obecnie najodpowiedniejsze dla przedstawicieli zawodów instruktora i egzaminatora. Podstawową gwarancję prawidłowego i zgodnego $\mathrm{z}$ interesem publicznym ich wykonywania stanowić mogą określone ustawowo, wysokie bariery dostępu do zawodu, obejmujące kwalifikacje zawodowe, doświadczenie oraz predyspozycje etyczne. W świetle przeprowadzonej analizy wyrażam przekonanie, że warunki te możliwe są do spełnienia poza samorządem zawodowym, którego ewentualne powołanie w przyszłości determinowane jest wzmocnieniem wewnętrznej organizacji i wzajemną integracją środowiska instruktorskiego i egzaminatorskiego ${ }^{49}$.

\section{STRESZCZENIE}

Przesłanki utworzenia samorządu zawodowego instruktorów nauki jazdy i egzaminatorów prawa jazdy

w świetle art. 17 ust. 1 Konstytucji Rzeczypospolitej Polskiej

Przedmiotem rozważań autora artykułu są przesłanki utworzenia samorządu zawodowego instruktorów nauki jazdy i egzaminatorów prawa jazdy. W opinii instruktorów i egzaminatorów wykonywane przez nich zawody należą do kategorii zawodów zaufania publicznego. W świetle przeprowadzonej analizy nie mają one konstytucyjnych cech pozwalających na uznanie, że w chwili obecnej samorząd zawodowy, o którym mowa w art. 17 ust. 1 Konstytucji RP, stanowi najlepszą formę ich organizacji, czego nie należy wykluczyć w przyszłości, przy spełnieniu określonych warunków.

Słowa kluczowe: instruktor nauki jazdy; egzaminator prawa jazdy; samorząd zawodowy; zawód zaufania publicznego

${ }^{48}$ Zob. B. Banaszak, Konstytucja.

49 Obecnie, zgodnie $z$ informacjami przedstawionymi przez inicjatorów powołania samorządu zawodowego instruktorów i egzaminatorów, w Polsce działa 5300 szkół jazdy, około 23000 instruktorów oraz około 2000 egzaminatorów. Przy tak dużej liczbie osób posiadających wymienione uprawnienia zawodowe ideę powołania samorządu zawodowego poparło jedynie 1490 osób. Zob. https://szie.pl/ (dostęp: 17.02.2021 r.). 


\section{SUMMARY}

Grounds for establishing a professional self-governing body of driving instructors and driving license examiners under art. 17 sec. 1 of the Constitution of the Republic of Poland

The subject of the article are the premises for establishing the professional self-government of driving instructors and driving licence examiners. In the opinion of instructors and examiners, their professions belong to the category of public trust professions. In the light of performed analysis, they do not have the constitutional features allowing to consider that at present the professional self-government (mentioned in Art. 17(1) of the Constitution of the Republic of Poland) constitutes the best form of their organization. This should not be excluded in the future, provided that the certain conditions are fulfilled.

Keywords: driving instructor; driving license examiner; professional selfgovernment; profession of public trust

\section{BIBLIOGRAFIA}

Banaszak B., Konstytucja Rzeczypospolitej Polskiej. Komentarz, Warszawa 2012.

Kłusek P., Państwo a samorządy zawodów zaufania publicznego, „Przegląd Prawa i Administracji” 2015, nr 103.

Kmieciak R., Samorząd gospodarczy $w$ Polsce. Rozważania na temat modelu ustrojowego, Poznań 2004.

Legat S., Lipińska M. (red.), Zawody zaufania publicznego a interes publiczny - korporacyjna reglamentacja versus wolność wykonywania zawodu. Materiały z konferencji zorganizowanej przez Komisję Polityki Społecznej i Zdrowia Senatu RP przy wspótudziale Ministerstwa Pracy i Polityki Społecznej pod patronatem Marszatka Senatu RP Longina Pastusiaka. 8 kwietnia 2002 r., Warszawa 2002.

Leoński Z., Samorząd terytorialny $w$ RP, Warszawa 2002.

Ożdżyński Z., Etyka i edukacja a bezpieczeństwo ruchu drogowego, „Przedsiębiorczość - Edukacja” 2008, t. 4.

Safjan M., Bosek L. (red.), Konstytucja RP. Tom I. Komentarz do art. 1-86, Warszawa 2016. 
Sarnecki P., Opinia o projekcie ustawy „Prawo o adwokaturze”, „Palestra” 1991, nr 1-2.

Sarnecki P., W sprawie wykładni art. 17 ust. 1 Konstytucji Rzeczypospolitej Polskiej, „Przegląd Sejmowy” 2001, nr 2.

Soboń S., Kodeks drogowy. Komentarz z orzecznictwem NSA, SN i TK. Część III. Ustawa o kierujacych pojazdami z komentarzem, Warszawa 2014.

Szlachta B. (red.), Słownik społeczny, Kraków 2004.

Żuraw P., Etyczne determinanty zarzadzania ośrodkami szkolenia kierowców $w$ świetle zmian prawnych obowiazujących od 2013 r., „Annales. Etyka w życiu gospodarczym” 2014, nr 2.

Żuraw P., Kodeks etyczny egzaminatora, „Szkoła Jazdy” 2011, nr 6. 
